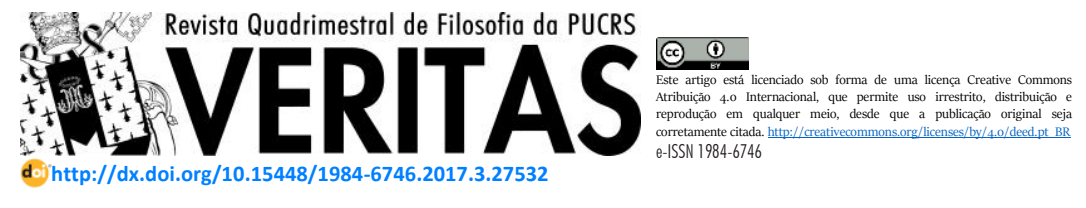

\title{
Disjuntivismo epistemológico e ceticismo radical
}

\author{
Epistemological disjunctivism and radical skepticism
}

\author{
Breno Ricardo Guimarães Santos 1
}

\begin{abstract}
Resumo: O disjuntivismo epistemológico é uma teoria filosófica que tem recebido uma atenção especial nos últimos anos. Particularmente porque ela tem sido encarada por muitos como uma via de renovação de discussões que vão desde a natureza da justificação das nossas crenças cotidianas até a possibilidade de desvendar as estruturas do ceticismo radical e responder ao problema estabelecido por ele. Duncan Pritchard é um dos autores que têm oferecido uma visão particular do disjuntivismo e maneiras de conceber tratamentos disjuntivistas para tais questões. Seu trabalho tem como fonte de inspiração, em grande medida, o trabalho seminal de John McDowell. Nesse artigo, eu apresento uma maneira de entender o problema cético radical e de que maneira o disjuntivismo epistemológico pretender oferecer soluções ao problema. Para isso, eu apresento a proposta disjuntivista geral de McDowell e discuto em que sentido essa proposta se diferencia da teoria disjuntivista defendida por Pritchard. Ao fim, eu tento mostrar como a abordagem de Pritchard pretender responder ao ceticismo radical não só apelando para uma leitura disjuntivista da nossa posição epistêmica, mas oferecendo uma revisão da nossa estrutura de razões.
\end{abstract}

Palavras-chave: disjuntivismo epistemológico; ceticismo radical; internalismo; externalismo.

\begin{abstract}
Epistemological disjunctivism is a philosophical theory that has received special attention in the recent years. Particularly because it has been seen by many as a way of renewing discussions that range from the nature of justification of our daily beliefs to the possibility of unveiling the structure of the problem of radical skepticism and of responding to it. Duncan Pritchard is one of the authors who have offered a particular view of disjunctivism and ways of conceiving of disjunctivist treatments to such questions. His work has as its main source of inspiration the seminal work of John McDowell. In this paper, I present a way of understanding the problem of radical skepticism and the manner in which epistemological disjunctivism aims to offer solutions to it. In order to do that, I present McDowell's general proposal and discuss in which way his account differs from Pritchard's own disjunctivism. At the end, I try to show how Pritchard's approach tries to respond to radical skepticism not only by appealing to a disjunctivist reading of our epistemic position, but also by offering a revision of our structure of reasons
\end{abstract}

Keywords: epistemological disjunctivism; radical skepticism; internalism; externalism.

\footnotetext{
${ }^{1}$ Pesquisador colaborador - Universidade de Brasília < breno.ricardo@gmail.com>
} 


\section{Introdução}

Em uma série de trabalhos recentes (2008, 2011, 2012, 2015, dentre outros), Duncan Pritchard defendeu uma posição em epistemologia que ele chamou de "Disjuntivismo Epistemológico". Se correta, essa posição seria, de acordo com ele, uma espécie de "cálice sagrado" da epistemologia (2012, p. 1.). Isso porque uma das vantagens do DE estaria no desafio que a teoria representaria para o impasse tradicional entre o internalismo e o externalismo epistemológico ${ }^{3}$, na medida em que seria um modo de conciliar as duas posições de maneira que os comprometimentos centrais de cada uma fossem resguardados. Com essa conciliação estabelecida, Pritchard sugere que seria possível desenhar e executar uma estratégia de resposta ao problema cético radical - essa resposta, segundo ele, não estaria disponível para posições tradicionais em epistemologia.

Na primeira parte deste trabalho, tratarei do Disjuntivismo Epistemológico como tese geral que não está necessariamente comprometida com a proposta conciliatória de Pritchard, mas que serve de fundamento para ela. Em seguida, apresentarei em detalhes o tipo de suporte epistêmico misto que Pritchard afirma estar disponível do ponto de vista disjuntivista toda vez que formamos crenças tendo como base a percepção. Por fim, discutirei em que sentido a identificação desse suporte epistêmico misto pode apontar para uma possível estratégia contra o ceticismo radical.

\section{Uma visão geral do disjuntivismo}

A proposta disjuntivista de Pritchard é, em grande medida, uma expansão da visão defendida por John McDowell sobre as características epistêmicas das nossas experiências perceptivas. Nesse sentido, um entendimento apropriado da proposta disjuntivista mais geral, incluindo aí a posição de McDowell pode nos ajudar a compreender de forma mais clara o que Pritchard tem em mente quando propõe seu DE particular e a compreender também a natureza da estratégia anticética que ele motiva.

\footnotetext{
${ }^{2}$ Usarei "DE", daqui em diante, para tratar da maneira particular que Pritchard articula a tese mais geral do disjuntivismo epistemológico.

${ }^{3}$ Tratarei desse impasse mais à frente.
} 
Considere o seguinte experimento mental: Em um mundo $M_{n}$, $\mathrm{Ana}_{\mathrm{n}}$ possui as mesmas crenças que Ana ${ }_{\mathrm{o}}$ no mundo $\mathrm{M}_{\mathrm{o}}$. Em ambos os mundos, Ana $_{\mathrm{n}}$ e Ana ${ }_{\mathrm{o}}$ formam as mesmas crenças, com base no mesmo tipo de justificação subjetiva. Por exemplo, tanto em $\mathrm{M}_{\mathrm{o}}$ quando em $\mathrm{M}_{\mathrm{n}}$, respectivamente, Ana ${ }_{\mathrm{o}}$ e $\mathrm{Ana}_{\mathrm{n}}$ formam suas as crenças com base naquilo que suas percepções oferecem como evidência para proposições acerca do mundo. No entanto, todas as crenças de Ana $_{\mathrm{n}}$ estão sendo produzidas de maneira artificial por um computador que alimenta Ana $_{\mathrm{n}}$ com informações falsas sobre o mundo, de modo que ela está sempre a formar crenças idênticas às de $\mathrm{Ana}_{0}$, mas que são por sua vez falsas. Suponha, então, que

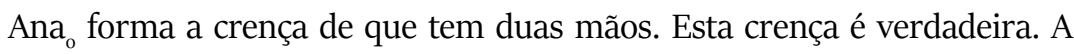
crença também é idêntica e tem mesmo suporte evidencial subjetivo que a crença de Ana $_{\mathrm{n}}$ de que ela tem duas mãos. No entanto, a crença de Ana é falsa, pois todos os dados da percepção que suportam de modo subjetivo sua crença a esse respeito foram criados por um computador cuja função é criar crenças falsas, mas idênticas às de $\mathrm{Ana}_{\mathrm{o}}$, a respeito do mundo. $\mathrm{Na}$ verdade, nem seria fisicamente possível que Ana tivesse de fato duas mãos dado que ela é apenas um cérebro em uma solução aquosa, dentro de uma cuba, conectada a esse computador manipulador. Portanto, enquanto a crença de $A_{n} a_{o}$ é verdadeira - ela de fato tem duas mãos, não podemos dizer o mesmo sobre a crença de Ana ainda que ela esteja em uma situação epistêmica subjetivamente indistinguível daquela na qual sua contraparte não-manipulada está.

Avaliemos, então, essa dicotomia entre duas situações epistêmicas supostamente concorrentes. De um lado temos o caso epistêmico positivo, no qual S possui uma crença verdadeira acerca do mundo, crença esta que é aparentemente suportada pelas evidências disponíveis para S. Competindo com este caso, temos uma situação contrafactual na forma de um caso epistêmico negativo no qual a contraparte manipulada de $S$ forma uma crença sobre os mesmos aspectos do mundo contidos da crença verdadeira de S, mas sua crença é falsa. Tal crença é falsa porque, nesse caso, todas as crenças da contraparte manipulada de $S$ são formadas por um mecanismo de enganação profunda. Até aí tudo bem. Não há nada de problemático em pensarmos que podem existir situações contrafactuais desse tipo. O problema surge, entretanto, quando pensamos que tanto $\mathrm{S}$ 
quanto sua contraparte manipulada não só estão de posse das mesmas crenças, mas ambas formam suas crenças tendo como base o mesmo tipo de justificação subjetiva. Tanto Ana $a_{0}$ quanto Ana $\mathrm{n}_{\mathrm{n}}$ formam suas crenças com base naquilo que suas percepções oferecem como evidências sobre como o mundo é.

Considerando que todos os dados da percepção que sustentam subjetivamente a crença que $\mathrm{Ana}_{\mathrm{n}}$ tem sobre o mundo são gerados por um computador cuja função é enganá-la em todas as suas crenças desse tipo, talvez fosse intuitivo pensarmos que a diferença deste caso para o caso positivo seja notável. Dada a diferença de origem, os casos epistêmicos positivo e negativo obviamente deveriam ser tratados de maneira diferente, certo? No entanto, uma defesa de tal intuição não parece tão óbvia quando investigamos a natureza dos dois casos de modo mais delicado. A questão cética central que se coloca é como podemos saber se estamos em um caso ou em outro? Do ponto de vista subjetivo não parece haver uma diferença substancial entre os casos para que essas perguntas sejam respondidas de pronto - ou pelo menos é isso que uma posição cética poderia defender. E se ela estiver correta, respostas como essa não parecem estar disponíveis nas ferramentas epistêmicas tradicionais. Assim o problema cético radical ${ }^{4}$ poderia se instalar: se não temos essas ferramentas, não podemos saber se somos como Ana ou $\mathrm{Ana}_{\mathrm{n}} \mathrm{e}$, por consequência, não podemos saber muitas das coisas nas quais acreditamos.

Não parece absurdo pensarmos que, ainda que causalmente falando, as experiências de $\mathrm{Ana}_{\mathrm{o}}$ e $\mathrm{Ana}_{\mathrm{n}}$ sejam diferentes, elas ainda são fundamentalmente o mesmo tipo de experiência. Dado que os estados doxásticos finais são os mesmos, indistinguíveis, que ferramenta nós disporíamos para defender que as experiências, do ponto de vista subjetivo, são diferentes? Um debate recente em Filosofia da Percepção tem se preocupado em oferecer um tratamento dessa distinção e uma rejeição da ideia de que experiências verídicas e experiências não-verídicas indistinguíveis são o mesmo tipo de experiência. Para alguns dos autores

\footnotetext{
${ }^{4}$ Por "problema cético radical" eu estou me referindo a um problema cético que, diferentemente de um ceticismo local, não coloca em dúvida apenas a possibilidade de conhecermos localmente proposições particulares, mas coloca em dúvida a possibilidade de conhecermos, ponto. Se não podemos descartar a possibilidade de que nossas crenças mais básicas não sejam casos de conhecimento, então grande parte ou a totalidade do nosso conhecimento parece estar comprometida.
} 
e autoras que defendem uma posição de distinção desse modo, as experiências não só são diferentes, como são radicalmente diferentes. De acordo com defensores dessa distinção radical (THAU, 2004; TYE, 2007; e BURGE, 2005, 2011), a experiência perceptiva tem um caráter disjuntivo. Em linhas gerais, a ideia é que experiências verídicas, como as de Ana, são de um tipo e experiências não-verídicas, como as de Ana, são de outro tipo radicalmente diferente - e o aspecto disjuntivo dessa posição consiste em dizer que experiências perceptivas são necessariamente ou de um tipo ou de outro.

Para entender melhor como as experiências em questão podem ser radicalmente diferentes, podemos considerar que experiências verídicas são experiências nas quais "i) o sujeito percebe coisas em seu ambiente; ii) seu ambiente é como parece para ele que é; e iii) para todas as propriedades $\mathrm{F}$, se algo que o sujeito percebe parece ser $\mathrm{F}$, isso é porque o sujeito percebe esse algo sendo F" (LOGUE, 2015, p. 199). Por exemplo: quando eu vejo um objeto com determinadas propriedades, parece para mim que o objeto tem essas propriedades, e isso se dá porque eu percebo essas propriedades. Ou seja, de acordo com essa definição, há o que W. A. N. G. Huaping chama de um caráter "genuinamente relacional" na experiência verídica - sem o objeto e suas propriedades, eu não posso ver que há um objeto e suas propriedades (HUAPING, 2011, p. 447).

Em contrapartida, uma experiência não-verídica é uma na qual pelo menos uma das condições acima não se dá. Em casos de ilusão, por exemplo, a condição (i) é cumprida ${ }^{5}$, mas não a condição (iii). Pense em uma situação em que você vê uma banana verde que, por conta da iluminação do ambiente, parece ser amarela para você. Neste caso, você percebe coisas no ambiente, e o ambiente, podemos supor, é da maneira que você pensa que ele é - por exemplo, você não é um cérebro em uma cuba -, mas as propriedades que você percebe e atribui ao objeto em questão não são do objeto (LOGUE, 2015, p. 200). No caso das Anas, por sua vez, a experiência perceptiva de Ana $a_{n}$ viola a condição (iii) da definição, pois as propriedades que $\mathrm{Ana}_{\mathrm{n}}$ percebe e atribui aos objetos no mundo não são propriedades destes objetos, mas são características alimentadas à

\footnotetext{
${ }^{5}$ Note que o sentido de 'percepção' sendo usado aqui é um sentido mais amplo que não exclui casos de alucinação como instâncias de percepção (nem toda percepção é verídica). Nesse caso, percebe-se um objeto ao alucinar à medida em que se apresenta à mente do sujeito uma representação do objeto como se ele estivesse no ambiente. É por isso que, nos casos acima, a condição (i) é cumprida.
} 
mente dela pelo computador manipulador. Podemos pensar ainda, mesmo que não seja fundamental para o caso, que o mundo não é como Ana $_{\mathrm{n}} \mathrm{O}$ imagina ser (violando (ii)). Assim teríamos um caso paradigmático de experiência não-verídica cujos aspectos fenomênicos são os mesmos de um caso paradigmático de experiência verídica como o de Ana $_{0}{ }^{6}{ }^{6}$

É esse aspecto fenomênico que, a despeito da distinção acima, estabelece uma barreira para propostas epistêmicas que pretendem estabelecer as condições necessárias e suficientes para termos justificação e conhecimento perceptivo. Dada a impressão visual que temos do mundo, parece ser o caso de que a evidência perceptiva que possuímos quando formamos nossas crenças cotidianamente subdetermina se somos pessoas normais, em uma situação epistêmica positiva, tendo experiências verídicas, ou se somos pessoas aprisionadas a uma situação epistêmica negativa, sendo enganadas através de uma alucinação indistinguível. Dado que a evidência perceptiva que possuímos para nossas crenças cotidianas parece suportar com mesmo peso as duas situações epistêmicas, ela falha em determinar se estamos em um caso ou em outro. E se esta evidência falha em determinar nossa posição epistêmica, é possível ver a abertura para que se instale um problema cético radical com base em um princípio epistêmico altamente plausível, conhecido como:

Princípio da Subdeterminação (PS): Se S sabe que p e q descrevem cenários incompatíveis, e ainda $S$ não possui uma base racional que favoreça $\mathrm{p}$ sobre $\mathrm{q}$, então $\mathrm{S}$ carece de conhecimento racionalmente suportado de p (PRITCHARD, 2015, p. 34)7.

A ideia do problema com base nesse princípio é de que se para cada percepção verídica que temos cotidianamente existe uma experiência análoga alucinatória subjetivamente indistinguível, não temos como saber, sob pena de violar o PS, se estamos em uma situação epistêmica positiva, formando crenças verdadeiras acerca do mundo. Alternativamente, temos:

\footnotetext{
${ }^{6}$ Precisamos tomar cuidado nesse ponto para não confundir teorias disjuntivistas epistêmicas com teorias disjuntivistas metafísicas. Esta discussão central em Filosofia da Percepção trata essencialmente do disjuntivismo metafísico, uma teoria segundo a qual os conteúdos das nossas experiências são radicalmente diferentes em casos de percepção verídica e enganação profunda. Embora ambos os tipos de propostas disjuntivistas se apoiem, de uma maneira ou de outra, em comprometimentos análogos oferecidos pelas teorias da percepção, uma posição não é equivalente a outra ou sequer a acarreta.

${ }^{7}$ Versões menos exigentes e um tratamento minucioso deste princípio podem ser encontrados em YALÇIN, 1992; BRUECKNER, 1994; COHEN, 1998; VOGEL, 2004; e PRITCHARD, 2005.
} 
Paradoxo Cético Radical - Evidencial (PCR - E): I: Eu não possuo suporte racional que favoreça minhas crenças cotidianas em vez da crença na hipótese cética; II: Se não possuo suporte racional que favoreça minhas crenças cotidianas em vez da crença na hipótese cética, então eu não possuo conhecimento racionalmente suportado (" $\mathrm{C}^{\star}$ ” daqui para frente) de proposições cotidianas; III: Eu possuo $C^{\star}$ de muitas coisas que acredito cotidianamente (PRITCHARD, 2015. p, 34).

Para conhecer perceptivamente as coisas no mundo, precisamos saber se nossa percepção nos conecta a essas coisas (LOGUE, 2015, p. 205.) Em outras palavras, precisamos saber se nossas experiências, e as crenças formadas com base nelas, envolvem perceber as coisas no mundo e não envolvem uma enganação massiva acerca dessas coisas. O disjuntivismo epistemológico ${ }^{8}$ é uma teoria recente em epistemologia que defende que podemos saber que estamos conectados ao mundo através da percepção. Em uma série de trabalhos (MCDOWELL, 1982, 1996, 2008, 2010, 2013; dentre outros), John McDowell saiu em defesa de um "disjuntivismo sobre a evidência perceptiva" (LOGUE, 2015, p. 206), uma teoria que rejeita a ideia de que nossa posição epistêmica está subdeterminada por nossa evidência em casos de crença perceptiva. Em linhas gerais, ele defende que a evidência perceptiva que temos para o caso positivo não só não subdetermina nossa posição, como também é diferente da evidência que temos nas situações epistêmicas negativas (MCDOWELL, 2002, p. 98).

A posição disjuntivista epistemológica inicial é, então, a de que nossas experiências verídicas não são apenas diferentes, do ponto de vista conceitual, das experiências não-verídicas indistinguíveis, mas elas são ainda um tipo de experiência suportada por evidências perceptivas que não estão disponíveis nos casos de ilusão ou de alucinação de mesmo conteúdo fenomênico. Segundo Logue, o "tipo especial de evidência" que temos quando experienciamos de forma verídica algo é, do ponto de vista disjuntivista, suficiente para nos colocar em uma posição de conhecermos coisas sobre o nosso ambiente. Já as experiências não-verídicas, dada a sua natureza "defeituosa", não podem nos colocar nessa posição (LOGUE, 2015, p. 206). O reconhecimento desse tipo especial de evidência é fundamental para podermos entender como McDowell se posiciona sobre

\footnotetext{
${ }^{8}$ Esse termo se originou em SNOWDON (2005) e foi utilizado de forma mais recorrente nos trabalhos de Pritchard, muitos dos quais eu menciono neste artigo.
} 
a estrutura do problema cético e seus atributos epistêmicos.

De acordo com ele, o problema cético é fruto de uma “interiorização do espaço de razões” (MCDOWELL, 2002, p. 98). Dado que aquilo que o cético conta como evidência perceptiva é apenas o que é comum entre os casos verídicos e não-verídicos, principalmente através das intuições sobre o peso que a fenomenologia dos casos tem para determinar nossa posição epistêmica, somos levados a pensar que as únicas razões que temos disponíveis para as nossas crenças perceptivas cotidianas são aquelas razões internas à nossa mente que não são capazes de acarretar a verdade daquilo que acreditamos com base na percepção. Essa interiorização do espaço de razões geraria, por sua vez, uma concepção equivocada desse espaço, que McDowell chama de concepção do "maior fator comum" (MFC). De acordo com MFC, o conteúdo da experiência perceptiva em casos verídicos e casos não-verídicos será sempre aquilo que os casos têm em comum. Por exemplo, o que há em comum entre os casos de Ana $_{\mathrm{o}}$ e Ana $\mathrm{n}_{\mathrm{n}}$ são as características fenomênicas dos dois casos, a maneira como o mundo parece para elas. Nesse caso, de acordo com MFC, o conteúdo de ambas as experiências perceptivas é essa mera aparência. O que é dado para Ana ${ }_{0}$ como suporte evidencial perceptivo seria aquilo que também estaria presente de qualquer modo, mesmo se a experiência de Ana ${ }_{0}$ fosse manipulada como a de Ana. De modo alternativo, como Macarthur (2003, p. 177) sugere, o que MFC representa é a ideia de que quando percebemos um objeto que é fenomenicamente idêntico àquilo que percebemos em uma alucinação, por exemplo, devemos explicar a indistinguibilidade entre as duas percepções através daquilo que é comum a elas. Dado que em um caso de alucinação não estamos conscientes de um objeto real existente, mas sim daquilo que ele chama de "ideia" sensorial do objeto, e que esta ideia também está presente quando experienciamos veridicamente, devemos entender a experiência perceptiva como uma instância mental na qual estamos "diretamente" conscientes de uma "ideia" sensorial deste objeto, e não necessariamente do objeto em si. A moral desta posição é a de que a única base empírica para a inferência sobre o mundo se dá por intermédio de um elemento comum a casos de enganação e casos comuns de percepção, fazendo assim uma transição brusca que, segundo McDowell, parte de uma ideia genuína de que somos falíveis para um ceticismo do "véu de ideias" (MCDOWELL, 1982, p. 472). 
McDowell defende que essa não é a única maneira de explicar a experiência perceptiva. Sua posição, entretanto, não rompe de maneira drástica com o exposto acima. McDowell assume uma postura ortodoxa no que diz respeito à nossa posição epistêmica (PRITCHARD, 2003, p. 275). Ele defende que nosso conhecimento envolve estarmos em uma posição apropriada dentro do espaço de razões, ou seja, envolve estarmos internamente justificados. Sua teoria é, no fim das contas, uma teoria epistêmica internalista, na qual razões desempenham um papel central na nossa aquisição e manutenção de conhecimento. Em linhas gerais, internalismo epistêmico ${ }^{9}$ é a posição segundo a qual o que conta como justificação para nossas crenças são fatores internos a nós. O que conta como interno, por sua vez, vai depender do tipo de posição internalista assumida. Para entender o que significa ser interno, nesse sentido, podemos seguir um grupo de internalistas que defendem que o conta como interno deve atender a uma demanda de acesso reflexivo ${ }^{10}$. Ou podemos nos alinhar com outro grupo menos popular que defende que justificação internalista é determinada pelos estados mentais de quem acredita em determinada proposição ${ }^{11}$. O externalismo epistêmico é, em grande medida, uma contraposição ao internalismo, sendo definido muitas vezes pelo tipo de objeção que apresenta a ele, seja em que forma este se apresente. O externalismo é a rejeição do internalismo no sentido em que, se conhecimento demanda justificação, esta justificação não é definida em termos internalistas, ela não é fundamentalmente definida por fatores internos a nós.

Segundo posições filosóficas identificadas com o internalismo acessibilista, por exemplo, aquilo que faz com que uma pessoa possua justificação para sua crença de que p sobrevém apenas dos estados aos quais essa pessoa tem um acesso reflexivo especial. De acordo com essa posição, todos os fatores que justificam a crença de um sujeito devem estar disponíveis para serem acessados através da reflexão; assim, as condições

\footnotetext{
${ }^{9}$ É importante notar que estou tratando aqui de internalismos e externalismos quanto à natureza da justificação, e não quanto à natureza do conhecimento. A suposição de partida é que há um terceiro elemento da definição de conhecimento que pode ser definido, em linhas gerais, em termos de justificação; e que há uma disputa sobre o que caracteriza este elemento.

${ }^{10}$ Esse grupo é conhecido como internalistas acessibilistas. CONEE e FELDMAN (200o) usam o termo em inglês accessibilism para se referir a essa posição.

${ }^{11}$ Esse grupo é conhecido como internalistas mentalistas. CONEE e FELDMAN (200o) usam o termo em inglês mentalism para se referir a essa posição.
} 
epistêmicas necessárias para que $S$ tenha justificação para sua crença de que $\mathrm{p}$ devem ter um suporte epistêmico interno, devem poder ser acessíveis pela reflexão independente ${ }^{12}$. Diferentemente do que defenderia uma posição externalista, por exemplo, o fato de determinada crença de $\mathrm{S}$ ter sido formada por um processo confiável de formação de crenças não conta como uma das condições epistêmicas que irão se somar para conferir a $\mathrm{S}$ a justificação proposicional necessária. A confiabilidade do processo e o fato da crença ter sido formada por este processo não se configuram como um elemento interno a $\mathrm{S}$, um elemento que pode ser acessado através da reflexão independente (PRITCHARD, 2012). Em resumo, a versão da posição internalista que nos interessa aqui diz que o suporte epistêmico internalista que $S$ tem para crer que p é constituído somente por fatos que S pode conhecer através da reflexão independente. Com a proposta internalista mais geral estabelecida (em sua versão mais popular), podemos pensar na proposta externalista como uma posição que se opõe de modo particular a tal demanda de acesso reflexivo e que faz uma defesa da necessidade de considerarmos nossa relação com o mundo como relevante para formação adequada de nossas crenças, no sentido em que o nosso sucesso em interagir adequadamente com o ambiente deve ter peso na avaliação da nossa posição epistêmica

Nesse sentido, a posição de McDowell, por ser alinhar à ideia de que nossa posição epistêmica é determinada pelas razões que possuímos - e podemos citar - quando formamos as nossas crenças perceptivas, pode ser entendida como alinhada também à ortodoxia epistemológica internalista. Essa postura, entretanto, carrega o que Pritchard chama de "radicalidade subjacente", pois seu propósito final é o de reconfigurar a maneira pela qual entendemos nossas razões (PRITCHARD, 2003, p. 275). De acordo com essa posição, em vez de explicarmos o conteúdo das nossas experiências perceptivas com base apenas naquilo que, do ponto de vista internalista clássico, é comum entre as experiências diferentes, precisamos começar a explicá-las com base naquilo que está presente em uma, mas não está presente em outra. Segundo McDowell:

[S]uponha que nós digamos - de maneira nenhuma de modo não-natural

\footnotetext{
${ }^{12}$ A ideia aqui não é que a reflexão é o único meio de acessar essas razões factivas, mas que as razões estão reflexivamente disponíveis sem a necessidade de qualquer intermédio empírico adicional. Usarei esse termo ao longo do texto para me referir ao que em língua inglesa é expresso por by reflection alone e que se refere ao exercício da reflexão sem a necessidade de suporte adicional que não seja de caráter exclusivamente introspectivo.
} 
- que a aparência de que tal coisa é o caso pode ser tanto uma mera aparência ou o fato de que tal coisa é o caso se fazendo manifesto a alguém através da percepção. Como antes, o objeto da experiência nos casos de enganação é a mera aparência. Mas não aceitaríamos que nos casos sem enganação o objeto da experiência seria também uma mera aparência, algo que fica aquém do fato em si. Pelo contrário, nós insistiríamos que a aparência que nos é apresentada nesses casos é uma questão do fato em si estar sendo exposto para o experienciador. (MCDOWELL, 1982, p. 472)

Ainda que alinhado ao internalismo, McDowell está argumentando contra a posição em epistemologia segundo a qual o domínio interior das ideias é fundamental para a explicação do nosso conhecimento cotidiano, mesmo que não tenha qualquer conexão substancial com o mundo externo. Argumentando contra a ideia presente na concepção MFC de que a única conexão racional que temos com o mundo se dá através de inferências incertas a partir das razões internas que temos para sustentar nossas crenças, ele pretende eliminar assim a acidentalidade intrínseca a uma concepção deste tipo e rejeitar os problemas que essa acidentalidade traria consigo, incluindo aí o problema cético radical.

No disjuntivismo sobre a evidência perceptiva de McDowell, conhecimento não é nada mais do que um posicionamento apropriado no espaço de razões, sem a necessidade de fazer qualquer inferência incerta, ou sem precisar suplementar esta exigência com qualquer condição de verdade. Isso porque o que ele considera como razões dentro desse espaço pode ser factivo. De acordo com sua posição, ver que $p$ é uma razão factiva no sentido em que ver que $p$ acarreta a verdade de que $\mathrm{p}$ - ou seja, da mesma maneira que dizemos que se alguém sabe que algo é o caso, então não é possível que este algo não seja o caso, não é possível vermos que p é o caso sem que seja o caso que p. E para McDowell, isso é tudo o que precisamos para termos conhecimento em casos paradigmáticos nos quais experienciamos veridicamente. Rejeitando, assim, a ideia presente em MFC, e no pressuposto internalista clássico contido no problema cético, de que nossas razões nos casos competidores da hipótese cética são as mesmas.

Alguém poderia objetar, entretanto, que a solução que McDowell oferece não tem nada a ver com a demanda cética representada anteriormente pelo PCR-E. Segundo esta demanda, se eu não posso 
distinguir entre uma situação epistêmica positiva e uma situação epistêmica negativa, então eu supostamente não tenho como possuir as razões necessárias para determinar se estou em um caso ou em outro; não possuo uma base racional sólida para preferir uma explicação em detrimento da outra. O disjuntivismo epistemológico não pareceria, então, capaz de mostrar que nós temos quaisquer ferramentas para distinguir os dois cenários. Se esse é o caso, não parece que o disjuntivismo oferece uma resposta que satisfaça a demanda cética impulsionada pelo problema mencionado. Essa objeção é crucial. Em especial, porque envolve a impressão óbvia de que a proposta de McDowell não encara de frente a suposta impossibilidade de distinguirmos entres os casos epistêmicos concorrentes. No entanto, essa ausência de confronto com tal impossibilidade não é um problema para sua posição. Sua posição é, na verdade, sobre algo diferente. O que McDowell está defendendo é que há uma explicação equivocada do espaço de razões, a partir da ideia de que há um vão entre as nossas razões para crer, particularmente no caso epistêmico positivo, e os elementos do mundo sobre o qual formamos crenças $^{13}$. Ele aceita que, se assumirmos essa postura filosófica, de fato chegaremos à conclusão de que a concepção do MFC está correta e o que importa, do ponto de vista evidencial para o conhecimento, é aquilo que é entregue pelas aparências e que estaria presente mesmo em casos de enganação profunda.

Segundo ele, essa não é a única maneira de olhar para as questões epistêmicas. Podemos pensar na relação evidencial de modo disjuntivo e concluir que, ainda que não possamos distinguir introspectivamente entre os casos, nossas evidências nesses casos são diferentes. Assim, nos casos positivos nós podemos citar razões factivas para nossas experiências verídicas do mundo, razões que nos colocam em posição de conhecer aquilo no que cotidianamente acreditamos através da experiência perceptiva. McDowell está confortável em não ser capaz de responder diretamente à aparente impossibilidade de distinguir entre os casos porque sua proposta disjuntivista pretende ser um tratamento diagnóstico dos pressupostos assumidos na posição cética radical. Para McDowell, sua proposta não é uma resposta direta ao ceticismo, ou um argumento anticético elaborado, mas sim um tratamento demonstrativo das falhas da

\footnotetext{
${ }^{13}$ Pritchard explora esse tema um pouco mais em PRITCHARD, 2003, p. 277.
} 
teorização cética, de como o ceticismo radical "expressa uma inabilidade de fazer sentido da ideia de acesso perceptivo direto aos fatos sobre o ambiente" (MCDOWELL, 20o8, p. 378). Esse quietismo ${ }^{14}$ de McDowell serve não para embarcar sua posição filosófica em uma argumentação anticética mais robusta, mas serve para guiar uma avaliação terapêutica de como e onde o cético assume posições falhas para construir problemas ilusórios, e uma recusa de se importar com tais problemas (MCDOWELL, 1995, p. 888). McDowell então não está discutindo diretamente com o problema cético, mas está contornando-o ao oferecer uma posição filosófica alternativa que não acarreta aquilo que a posição cética radical acarreta, e que "libera o tráfego" para podermos ter conhecimento daquilo que acreditamos no dia a dia. Nessa proposta alternativa, como apontei acima, nós podemos oferecer razões factivas para nossas crenças formadas a partir de experiências perceptivas verídicas. As razões agora não estão mais interiorizadas, como elas estão nos pressupostos céticos. As razões agora têm uma natureza híbrida, são externas e internas.

Pritchard pensa que McDowell tem as ferramentas necessárias para avançar sua posição de forma mais corajosa, na direção de uma teoria anticética forte, uma estratégia que responda diretamente ao argumento cético radical. Em uma série de trabalhos recentes, Pritchard ofereceu um tratamento da posição diagnóstica de McDowell. A diferença central entre as duas propostas disjuntivistas tão semelhantes é que, enquanto McDowell oferece uma postura quietista diante do problema cético, Pritchard enfrenta frontalmente o problema e oferece uma saída a ele, ao mesmo tempo em que conciliaria as posições filosóficas que acabam gerando o problema em questão, ou gerando uma desconfiança de que há qualquer saída plausível para ele. No que segue, explorarei alguns pontoschave deste desenvolvimento anticético empreendido por Pritchard para fazer um sentido maior de uma posição disjuntivista epistêmica de tipo mcdowelleano.

\section{Uma visão particular do disjuntivismo}

Em Epistemological Disjunctivism (2012, p. 13), Pritchard

\footnotetext{
${ }^{14} \mathrm{O}$ termo quietista, como referência à postura filosófica adotada por McDowell, que tem como base uma metodologia diagnóstica e de esclarecimento, em vez de uma proposta mais direta contra o ceticismo, pode ser encontrado em MACARTHUR, 2003, p. 175; e em PRITCHARD, 2003, p. 277.
} 
defendeu a seguinte tese geral de seu DE: Em casos paradigmáticos de conhecimento, um agente $S$ tem conhecimento perceptivo de que $\mathrm{p}$ em virtude de estar de posse de suporte racional $\mathrm{R}$, para sua crença de que $\mathrm{p}$, que é tanto factivo (ou seja, a ocorrência de $\mathrm{R}$ acarreta p) quanto reflexivamente acessível para $\mathrm{S}$.

Há dois aspectos mais salientes nessa tese geral que merecem uma explicação mais cuidadosa. Em primeiro lugar, o que alguém que defende uma tese do tipo quer dizer quando diz que em casos paradigmáticos de conhecimento nós possuímos suporte racional factivo? E em segundo lugar, o que ele pretende nos informar quando diz que este suporte, em especial, é reflexivamente acessível?

Uma consequência comum da adoção, no contexto de crenças perceptivas, de uma posição internalista quanto à justificação é a adoção também de uma ideia associada à problemática cética conhecida como a Tese do Novo Gênio Maligno (NG). Segundo essa visão, a base racional reflexivamente acessível que possuímos em casos epistêmicos positivos possui o mesmo peso no trabalho epistêmico de suportar nossas crenças cotidianas que o suporte racional que nossa contraparte do caso epistêmico negativo possui para sua crença de mesmo tipo. Ou seja, mesmo que estejamos em um caso paradigmático de experiência perceptiva verídica, como é o caso de $\mathrm{Ana}_{0}$, a base racional que temos para formar nossas crenças é perfeitamente compatível com a possibilidade de sermos como $\mathrm{Ana}_{\mathrm{n}}$, sendo massivamente enganados por um computador cuja função é nos enganar sempre. Isso porque o suporte de Ana ${ }_{0}$, tal ideia sugere, não é melhor que o suporte que sua contraparte possui ao formar crenças que são em grande medida falsas. O trabalho central do DE é rejeitar essa tese, e rejeitar também a tese adicional gerada por ela que estabelece que nossa posição epistêmica em casos ordinários positivos não é melhor que nossa posição epistêmica em casos de enganação, a Tese da Insularidade de Razões (TIR). A ideia disjuntivista que está presente na proposta central de Pritchard sobre o DE é que as posições epistêmicas de Ana $_{\mathrm{o}}$ e $\mathrm{Ana}_{\mathrm{n}}$, ao contrário do que sustenta quem defende as ideias internalistas acima, são radicalmente diferentes em tipo (PRITCHARD, 2015, p. 126). De modo geral, o DE defende que os casos são radicalmente diferentes porque o suporte racional que elas possuem em experiências perceptivas verídicas e não-verídicas é diferente ao ponto de não compartilhar qualquer componente comum relevante - o que é 
diametralmente diferente do que defende a NG. O que faz com que esta posição seja disjuntivista, como vimos, é a defesa de que ou experienciamos veridicamente e assim possuímos um tipo específico de suporte racional para nossas crenças perceptivas ou experienciamos de forma não-verídica e temos um outro tipo diferente de suporte racional para as crenças formadas com base na percepção.

Para Pritchard, o suporte epistêmico que temos quando formamos crenças nas condições positivas paradigmáticas, como é o caso de alguém que forma uma crença de que há uma árvore no jardim com base na percepção verídica de uma árvore no jardim, consiste no fato de que nós vemos que a proposição-alvo em questão é o caso - nós vemos que há uma árvore no jardim. Ver que há uma árvore no jardim é a base factiva que $\mathrm{S}$ tem para crer que há uma árvore no jardim. E em casos paradigmáticos de crença perceptiva, o suporte factivo que $\mathrm{S}$ tem para crer que há uma árvore no jardim é, segundo ele, um suporte reflexivamente acessível para S. Suporte este que, associado à crença verdadeira de $\mathrm{S}$, é suficiente para que $S$ possua conhecimento perceptivo de que há uma árvore no jardim. A factividade de ver que $p$ está na ideia de que, necessariamente, se for o caso que vemos que $p$ então p é verdadeira. Não é possível, e isso é logicamente e epistemicamente pacífico, que vejamos que p sem que p seja o caso. Eu não posso ver que há uma árvore no jardim sem que haja uma árvore no jardim. Uma criança pequena, entretanto, poderia ver uma árvore no jardim sem ver que o objeto no jardim é uma árvore. Note que a partícula "que" carrega consigo um peso conceitual que a mera experiência perceptiva verídica não-paradigmática não carrega. Crianças pequenas (ou animais não-humanos) podem ver objetos, mas supõe-se que elas são incapazes, pelo menos de maneira confiável, de associar a experiência perceptiva ao conceito daquilo que se experiencia.

Até então temos um suporte epistêmico externalista típico, já que quando aceitamos ver que $p$ como suporte para nossas crenças perceptivas cotidianas, parece que estamos aceitando que é possível termos uma crença suportada por fatores que são externos às nossas mentes, e que não nos são, necessariamente, acessíveis ${ }^{15}$. A ideia de admitir esse tipo de

\footnotetext{
${ }^{15}$ De modo natural, alguém poderia defender que, dado que ver que $p$ envolve o uso da visão, por exemplo, há um elemento interno (no sentido em que envolve nossa cognição) que mina a externalidade da base epistêmica. Essa é, entretanto, uma leitura muito estreita do que está em jogo na discussão entre externalistas e internalistas. $\mathrm{O}$ externalista tradicional não tem problema algum em conceber suportes epistêmicos que sejam internos nesse sentido. Afinal, alguns casos paradigmáticos de conhecimento para externalistas - confiabilistas, em especial - dizem
} 
factividade como suporte para crenças perceptivas cotidianas não é uma inovação da posição disjuntivista. Pritchard comenta que o apelo para a factividade das experiências está presente no nosso uso cotidiano da linguagem e na nossa prática cotidiana de oferecer razões para as mais diversas crenças que formamos (PRITCHARD, 2012, p. 17). Suponha, como ilustração, que uma chefe liga para sua funcionária A e pergunta se a funcionária $\mathrm{B}$ está presente no trabalho. Ao receber uma resposta afirmativa de A, a chefe, que erroneamente supõe que B sempre falta ao trabalho quando ela não está, pergunta se A realmente sabe que B está no trabalho. Seria natural e nada inovador pensarmos que A pode responder à sua chefe dizendo que "sim, eu estou vendo que B está na sentada na mesa ao lado" (PRITCHARD, 2012, p. 17). A ideia aqui é que é natural conceber que uma maneira de responder a um desafio acerca do nosso conhecimento perceptivo está na prática de citar razões factivas em defesa de nossa alegação de conhecimento.

Esse ponto pragmático é importante em um sentido específico. Ainda que pensemos que o guia das conviçcões de senso comum não seja infalível, é importante notar que o DE está pelo menos alinhado a uma posição intuitiva sobre nossas alegações de conhecimento. Ou seja, Pritchard assume uma posição alinhada com a maneira padrão pela qual ofertamos razões paras as crenças que temos. Segundo ele, ainda que esse status padrão seja derrotável, parece ser o caso de que é o DE que está trabalhando com uma posição de senso comum e é a posição do seu potencial detrator que estaria oferecendo uma visão revisionista sobre a nossa prática epistêmica (PRITCHARD, 2012, pp. 17-18). O jogo de oferecer razões, todavia, é um jogo que favorece um vocabulário internalista típico. Ainda que formemos nossas crenças com a base factiva de caráter externalista descrita acima, a prática de oferecer razões de suporte à nossa posição epistêmica parece pressupor uma ideia internalista da estrutura de razões. Pressupõe em larga medida que entendamos a factividade da experiência como uma razão que está disponível para nós, cognitivamente.

respeito a crenças verdadeiras formadas através da visão e da memória. Visão e memória, entretanto, são fontes de justificação, mas não são necessariamente aquilo que justifica a crença de alguém na proposição-alvo. A justificação dessa crença está, segundo o externalismo, condicionada à confiabilidade do processo (nesse caso o processo é a própria fonte) de formação de crença. Ver que $p$, ou seja, a percepção verídica paradigmática de que p, é, neste sentido, absolutamente confiável, dado que acarreta a verdade de que p. Se a proposta estiver certa, então, o suporte epistêmico que temos em casos como esse é um suporte que satisfaz adequadamente o que é exigido pelo externalismo epistêmico, de maneira que garante uma conexão objetiva confiável das nossas crenças com o mundo. 
Ou, em termos acessibilistas, que nos é acessível através da reflexão. O DE defende que ver que $p$ é base factiva que suporta crenças paradigmáticas desse tipo e que essa base pode servir como razão reflexivamente acessível para a pessoa que forma a crença de que as coisas são como ela as percebe. Vejamos como isso se dá.

Ao dizer que ver que $p$ é reflexivamente acessível à pessoa que forma uma crença perceptiva paradigmática, o disjuntivista quer dizer que essa pessoa pode saber através da reflexão independente que ela está de posse desse suporte epistêmico relevante. O status de acessibilidade é derivado de uma posição pouco controversa dentro do debate epistemológico. A ideia geral, cara ao internalismo acessibilista, é que todos aqueles itens epistêmicos que podem ser citados como o suporte racional para uma crença sobre o mundo são itens que são acessíveis através da reflexão à pessoa que os cita. Pense, por exemplo, no caso em que alguém cita como suporte racional para sua crença de que um animal enjaulado é uma zebra, e não uma mula disfarçada de zebra, a ideia de que o zoológico não teria motivo algum para realizar a enganação, ou que a enganação custaria muito dinheiro para o zoológico, ou poderia até custar o emprego da responsável pelo monitoramento dos animais, etc ${ }^{16}$. Todas essas razões são fatos cuja posse o agente em questão pode conhecer através da reflexão independente. O agente pode saber que está de posse dessas razões sem precisar realizar qualquer investigação empírica adicional a respeito delas. E se a formulação do internalismo estiver correta, na ausência de derrotadores para essas razões, essa pessoa poderia saber com base no conjunto de razões reflexivamente acessíveis que o animal enjaulado é uma zebra e não uma mula.

Ver que $p$, sugerirá um defensor do DE, pode ter a mesma natureza racional explicitada acima. Dado que podemos citar que vemos que p como razão (ou uma das razões) para nossas crenças perceptivas cotidianas de que $\mathrm{p}$, ver que $p$ ocupa o mesmo espaço na economia epistêmica que outros tipos de razões não-factivas. Podemos saber que

\footnotetext{
${ }^{16}$ Esse é um caso famoso que pode ser encontrado no tratamento que Fred Dretske dá ao problema cético local. Em linhas gerais, sua hipótese cética pode ser descrita da seguinte forma: imagine uma visitante de um zoológico formando a crença de que o animal que vê é uma zebra - o animal parece uma zebra, há uma placa na jaula indicando que o animal é uma zebra, etc.; em seguida, entretanto, a visitante é apresentada à possibilidade cética de que aquele animal não seja uma zebra, mas uma mula disfarçada de forma indistinguível de uma zebra real. A intuição por trás deste exemplo é a de que se alguns dos nossos pressupostos epistêmicos estão corretos, se esta visitante não puder saber que o animal não é uma mula disfarçada de modo a ser indistinguível de uma zebra, ela não pode saber que o animal que vê é uma zebra. (DRETSKE, 1970). Tratarei de uma versão desse caso na próxima seção.
} 
estamos de posse desse item epistêmico sem a necessidade de embarcarmos em uma investigação empírica adicional ${ }^{17}$. E esse suporte, por servir como base racional citável na defesa do nosso conhecimento, seria um suporte reflexivamente acessível à pessoa que forma a crençaalvo, um suporte cuja posse podemos conhecer olhando para dentro da nossa cognição. A demanda acessibilista central parece, então, ser cumprida pelo DE. Tendo cumprido essa demanda, Pritchard irá sugerir, estamos em posição de oferecer uma resposta apropriada ao PCR-E com base em um entendimento disjuntivista da natureza das nossas crenças perceptivas, associado a uma distinção que não só defensores do DE deveriam adotar, mas que, segundo Pritchard, é fundamental para empreendimentos epistemológicos de modo geral. É dessa resposta e dessa distinção que tratarei na seção final do trabalho.

\section{Uma visão disjuntivista anticética}

Considere o seguinte caso: Bia está em um zoológico e, olhando para o animal dentro de uma jaula cuja placa frontal informa que é uma zebra, forma a crença de que o animal enjaulado é uma zebra. Bia não tem quaisquer razões para duvidar que aquele animal é uma zebra. E, de fato, o animal é uma zebra - e o ambiente é como Bia imagina que ele seja. A crença de Bia de que o animal que ela está olhando é uma zebra é verdadeira. A leitura do status epistêmico de Bia nesse caso não parece, à primeira vista, ser motivo de disputa. Parece ser o caso de que, concedidas algumas condições básicas, tanto posições internalistas quanto posições externalistas aceitariam que Bia sabe que o animal enjaulado é uma zebra. O que diria o DE sobre esse caso? Para o DE, Bia sabe que o animal

\footnotetext{
${ }^{17}$ Por conta da ameaça daquilo que Pritchard chamou de "o problema do acesso" (PRITCHARD, 2012, p. 20), segundo o qual a formulação disjuntivista estaria permitindo a possibilidade de conhecimento a priori e completamente nãoempírico de fatos sobre o mundo, é importante notarmos a presença da expressão "investigação empírica adicional" nessa passagem. Acredito que a explicação que John Greco (2014, p. 117) oferece ao sentido fraco de acesso reflexivo empregado pro Pritchard esclarece a importância dessa expressão: "[Pritchard] explora uma ambiguidade na frase 'conhecível através da reflexão independente'. Uma coisa que podemos querer dizer aqui é 'conhecível inteiramente através da reflexão, em oposição à investigação empírica'. Esse sentido geraria o resultado problemático - de que alguém pode saber de modo a priori que vê que p, e assim saber de modo a priori que várias proposições empíricas são verdadeiras. Um sentido mais fraco da frase, entretanto, é 'conhecível sem investigação empírica adicional'. É apenas neste sentido mais fraco, Pritchard pontua, que estão envolvidas as alegações disjuntivistas sobre o acesso reflexivo. Ou seja, quando o disjuntivista alega que podemos ter acesso reflexivo a bases factivas (por exemplo, de que vemos que $p$ ), a alegação é de que podemos ter esse acesso sem uma investigação empírica adicional. Mas, crucialmente, alguém pode saber que vê que $p$ com base em ver que $p$ [on the basis of seeing that $p$ ]. E, desse modo, não é a priori, tampouco sem quaisquer meios empíricos, que tal conhecimento é gerado.” (Itálicos no original)
} 
enjaulado é uma zebra. A explicação para isso estaria na ideia, central à proposta, de que Bia está de posse razões factivas que servem de suporte epistêmico para sua crença perceptiva em questão. Bia vê que o animal enjaulado é uma zebra e, dado que nada no exemplo se apresenta como impedimento para a crença, Bia pode acessar essa razão factiva de maneira reflexiva, pode saber que vê que é uma zebra, no sentido em que ver que é uma zebra é transparente para ela e serve como suporte internalista para sua crença de que o animal enjaulado é uma zebra. Esse ponto, como mencionado acima, é central para o disjuntivismo. Para o DE, este é nada mais do que o diagnóstico padrão de um caso paradigmático de conhecimento perceptivo.

Mais uma vez, alguém poderia objetar que a ideia de que temos acesso reflexivo às nossas razões factivas, que podemos saber pela reflexão independente que estamos de posse delas em casos paradigmáticos de conhecimento, como é o caso de Bia, é inconciliável com o fato de que há cenários indistinguíveis nos quais continuamos supondo que estamos de posse de tais razões. Cenários nos quais não temos qualquer conexão objetiva sólida com aquilo que acreditamos que estamos experienciando. Considere, por exemplo, uma variação do caso de Bia como contraponto: Bia* está em um zoológico e, olhando para o animal dentro de uma jaula cuja placa frontal informa que é uma zebra, forma a crença de que o animal enjaulado é uma zebra. Bia* não tem quaisquer razões para duvidar que aquele animal é uma zebra. No entanto, o animal não é uma zebra, mas uma mula minuciosamente disfarçada para ser confundida com uma zebra. Bia*, como Bia do exemplo original, não tem razões para duvidar de que o animal é uma zebra, não é uma pessoa dotada de habilidades especiais para distinguir zebras de mulas minuciosamente disfarçadas - ela não é, por exemplo, uma zoóloga especializada em equídeos. Portanto, embora Bia* pense que vê que o animal enjaulado é uma zebra e, com base nisso forme a crença correspondente, sua crença é falsa e ela não teria como notar a falsidade, dadas as configurações do caso em questão.

Esse problema é o que Pritchard chama de "problema da distinguibilidade". Ele consiste em duvidar do potencial epistêmico da autoridade de primeira pessoa (first-person authority) que temos com relação ao conteúdo de nossa experiência em casos de crença perceptiva. De acordo com este problema, se temos acesso reflexivo à razão factiva 
relevante, cuja posse podemos reconhecer através da introspecção, por que ainda somos incapazes de distinguir entre o caso de Bia e o caso de Bia*? Por que, estando de posse dessa razão, não podemos determinar de modo decisivo se estamos no caso positivo ou no caso negativo? Deveria ser o caso, diz a objeção, que fosse fácil fazer tal distinção. Para que isso acontecesse, bastaria que víssemos que estamos de posse da razão relevante (PRITCHARD, 2012, p. 21). No entanto, parece implausível pensarmos que Bia pode se posicionar decisivamente sobre essa questão, para a qual ela não teria qualquer habilidade especial. Assim, se o suporte epistêmico que Bia possui no caso positivo não é forte o suficiente para colocá-la em posição de fazer essa distinção, como ele poderia ser forte o suficiente para colocar Bia em posição de saber que o animal enjaulado é uma zebra?

Penso que este é o problema central que o DE precisa enfrentar para poder se afirmar como uma teoria adequada sobre casos paradigmáticos de conhecimento perceptivo. O problema é central também para uma possível resposta que a proposta possa oferecer ao problema cético radical. Dado que o problema parece se sustentar fortemente na ideia de que os dois cenários em questão são indistinguíveis, uma resposta disjuntivista ao problema da distinguibilidade vai, com sorte, poder ser estendida a uma posição mais robusta sobre o problema cético radical. Pritchard defende que essa resposta está disponível. Segundo ele, há uma distinção importante, e anterior à distinção em disputa nos casos acima, que vem sendo ignorada em discussões epistemológicas, mas que poderia oferecer insights capazes de desfazer algumas limitações que certos debates epistemológicos contemporâneos corriqueiramente enfrentam. Essa distinção é entre o que ele chama de suporte epistêmico discriminatório e suporte epistêmico de favorecimento (PRITCHARD, 2012, p. 63) que, por praticidade, chamarei respectivamente de SED e SEF daqui em diante. Para entender a importância que Pritchard dá a essa distinção, precisamos considerar com cuidado a que tipo de comprometimento sua proposta de distinção pretende se contrapor. Segundo ele, teorias epistemológicas ${ }^{18}$, em sua grande maioria, assumem um princípio de discriminação que diz que se $S$

\footnotetext{
${ }^{18} \mathrm{E}$ isso fica mais claro em teorias que assumem explicitamente exigências de discriminação visual em suas formulações, como é o caso de teorias relevantistas sobre o conhecimento - como a teoria das Alternativas de Relevantes defendida por Fred Dretske (DRETSKE, 1970).
} 
tem conhecimento perceptivo de que p e $S$ sabe que outra alternativa (conhecidamente inconsistente) q não é o caso, então S deve ser capaz de discriminar perceptivamente entre o objeto em questão em p e o objeto em questão em q (PRITCHARD, 2012, p. 73).

A sugestão de Pritchard é que concepções de conhecimento necessariamente atreladas a uma habilidade perceptiva discriminatória estão erradas. Para ele, é possível conhecermos perceptivamente sem necessariamente apelarmos para habilidades desse tipo. A ideia é que se rompa com o pressuposto da discriminação perceptiva ao mesmo tempo em que mantemos intactos alguns outros princípios epistêmicos, esses sim, Pritchard irá defender, essenciais para o conhecimento perceptivo paradigmático. Para o autor, a dificuldade que enfrentamos ao tentar atribuir conhecimento perceptivo a Bia de que o animal enjaulado é uma zebra não se dá apenas por conta de alguma tensão com algum princípio de discriminação. O problema, para ele, parece ser ainda mais fundamental que esse, pois afeta diretamente o suporte evidencial que Bia teria para sua crença de que o animal é uma zebra e sua crença, produto de uma dedução competente, de que o animal não é uma mula minuciosamente disfarçada. A tensão do problema seria, assim, com os seguintes princípios epistêmicos:

Princípio da Transmissão Evidencial (PTE): Se S sabe perceptivamente que p em virtude do conjunto de evidências E, e S deduz competentemente $\mathrm{q}$ de $\mathrm{p}$ (acreditando que q enquanto mantém seu conhecimento de que $\mathrm{p}$ ), então $\mathrm{S}$ sabe que q e esse conhecimento é suficientemente suportado por E (PRITCHARD, 2012, p. 75) ${ }^{19}$; e

Princípio do Favorecimento: Se S (i) sabe que p, e (ii) sabe que q, e (iii) sabe que p acarreta q, então $S$ tem melhor evidência (evidência que torna a proposição mais provável de ser verdadeira) em suporte de sua crença de que p do que de uma crença de que não-q (PRITCHARD, 2012, p. 76).

Como vimos, do ponto de vista do pressuposto da discriminação, a evidência que Bia possui para pensar que o animal enjaulado é uma zebra não parece oferecer nada que suporte qualquer avaliação da alternativa. Afinal, Bia não é zoóloga ou sequer teve a possibilidade de examinar o animal de perto para confirmar que ele não é uma mula minuciosamente

\footnotetext{
${ }^{19}$ Outras formulações do princípio podem ser encontradas em DAVIES, 2004; e WRIGHT, 2004.
} 
disfarçada. O exemplo que Pritchard oferece para ajudar a ilustrar essa tensão é o de uma detetive que deduz do seu conhecimento evidencialmente suportado de que A é o assassino que B não é o assassino. E ele completa com a pergunta: como podemos ter evidência que suporta de modo suficiente nossas crenças, mas que falha em suportar de modo suficiente proposições que se seguem dedutivamente delas? No caso da detetive, como ela pode não saber que B não é o assassino? Isso não parece possível, dado que o conjunto de evidências que suportam sua crença-alvo é automaticamente transmitido para sua crença na negação da alternativa. No caso de Bia, como ela pode não saber que o animal enjaulado não é uma mula disfarçada? A explicação encontrada na tradição é simples: PTE é violado porque a exigência da discriminação é violada - Bia não está de posse do SED, do suporte epistêmico discriminatório, que parece ser exigido para que se cumpra o PTE não seja violado. E com o PTE violado, Bia não está em posição de conhecer perceptivamente a proposição-alvo em questão.

Uma análise do Princípio do Favorecimento nos entrega um resultado semelhante. Note que esse princípio nada mais é que uma versão menos exigente do Princípio da Subdeterminação (PS), que apresentei no começo do trabalho. Nesse caso específico, a tensão é menos comprometedora do que a tensão cética radical gerada anteriormente. $\mathrm{O}$ ponto aqui é saber como alguém pode conhecer uma proposição p e saber que essa proposição acarreta a negação de uma segunda proposição q, e ainda assim não estar de posse de melhor evidência para crer que p do que para crer que q, uma evidência ou um conjunto de evidências que favoreça a crença de que $\mathrm{p}$ sobre a crença de que q? Trocando em miúdos no presente exemplo, se Bia sabe que o animal é uma zebra, e sabe que o animal não é uma mula, então parece que Bia precisa estar de posse de evidências que favoreçam a preferência pela primeira crença em detrimento da negação da segunda. No entanto, dado que aquilo que, do ponto de vista tradicional, poderia servir como evidência - o SED - está indisponível para Bia, então Bia não está de posse de melhor evidência para sustentar a crença-alvo. O PS, então, é também violado.

Pritchard discorda de ambos os vereditos. Para ele, é possível realinhar nossos pressupostos epistêmicos e perceber que Bia, de fato, está em uma posição evidencial muito mais forte do que essa leitura parece supor. Uma posição que, segundo ele, é forte o suficiente para satisfazer o 
PTE e o PS. Para isso, afirma, precisaríamos substituir o tipo de suporte epistêmico exigido para que tanto PTE e PS sejam satisfeitos em casos de crenças perceptivas. De acordo com sua posição, quando dizemos que Bia sabe que o animal enjaulado é uma zebra apenas vendo que o animal é uma zebra, queremos dizer muito mais do que simplesmente afirmar que Bia adquire conhecimento apenas olhando para o animal, ou seja, tendo como evidência apenas a cena visual diante dela que, dadas as características do caso, é indistinguível da cena visual no caso de enganação. Meramente olhar para um objeto não gera consequência epistêmica para a pessoa que olha o objeto. Ver que $p$, diferente de meramente ver $p$, envolve o domínio de conceitos fundamentais para que se extraia qualquer resultado epistêmico dessa experiência. Para Pritchard, ver que $p$ não só envolve esse tipo de domínio conceitual como envolve também, com frequência, uma classe ampla de habilidades e conhecimento de fundo como suporte adicional que não está explicitado na ideia de que "alguém sabe que p é o caso apenas vendo que p". Pessoas em casos paradigmáticos de conhecimento perceptivo são capazes de apelar para considerações adicionais que favorecem um cenário sobre o outro, ainda que não o façam. Essas pessoas estão de posse de um SEF sem necessariamente estar de posse de um SED, ou seja, sem estar em posição de discriminar entre os casos epistêmicos contrapostos. Uma pessoa que conhece perceptivamente $\mathrm{p}$, nesses casos, está de posse de uma gama de evidências que não se resumem apenas à evidência fornecida pela experiência visual. Alguém como Bia, segundo Pritchard,

[...] irá certamente possuir todo tipo de evidência de fundo disponível para ela que favoreça epistemicamente o cenário da zebra sobre o cenário alternativo da "mula [minuciosamente] disfarçada". Isso irá incluir evidência sobre a plausibilidade dessa enganação, a probabilidade de ela ser percebida, as penalidades que seriam impostas caso ela fosse descoberta, o esforço que alguém precisaria fazer para tornar a enganação plausível (incluindo os custos que esta pessoa teria), e assim por diante. Coletivamente, essas considerações certamente fornecem uma base epistêmica suficiente para preferir o cenário da zebra à sua alternativa cética local. Mas se isso está certo, então nosso sujeito pode saber que ela está no cenário da zebra em vez do cenário concorrente da "mula [minuciosamente] disfarçada”, ainda que ela não possa distinguir perceptivamente entre estes dois cenários - especificamente, ainda que ela não possa distinguir perceptivamente entre zebras e mulas [minuciosamente] disfarçadas (PRITCHARD, 2015, pp. 131-132). 
Pritchard defende que há uma maneira de saber que estamos em um cenário em vez de outro mesmo sem que isso seja uma maneira de discriminar através da percepção entre os dois cenários. A diferença operativa aqui, como mencionado acima, é que é possível que estejamos de posse de um SEF sem estar de posse de um SED. Assim, Bia poderia estar de posse de evidência que respeita a nossa concepção cotidiana de evidência mesmo sendo incapaz de discriminar perceptivamente entre cenários epistêmicos incompatíveis. Note que essa maneira de apresentar o suporte evidencial que Bia possui ao formar sua crença de que o animal é uma zebra satisfaz os dois princípios que Pritchard defendeu serem essenciais para o conhecimento, o PTE e o PS. Por outro lado a exigência discriminatória, ainda que esteja presente no debate epistêmico tradicional, não respeita o nosso uso cotidiano da noção de evidência. Ela é muito forte, por isso deve ser rejeitada, junto com o problema da distinguibilidade! Note que essa distinção feita por Pritchard não precisa necessariamente apelar para o DE. Pelo contrário, a posição de Pritchard é que essa distinção precisa ser feita e adotada por qualquer pessoa, em defesa de qualquer posição epistêmica que quer fazer sentido do debate evidencial, quando o que está em jogo é avaliação de crenças perceptivas. O fato de tal distinção ser largamente ignorada é o que, segundo ele, nos limita em avaliar casos como esses, como o caso de Bia e da zebra (PRITCHARD, 2012, p. 81).

Parece natural pensar que, quando confrontada com a possibilidade de erro, Bia pode lançar mão de um conjunto adicional de evidências para sustentar sua crença-alvo (e até a crença na negação da possibilidade de erro). Com frequência, essas evidências adicionais são do tipo de favorecimento e não do tipo discriminatório. E essas evidências são normalmente ignoradas porque os modos de articular o problema parecem sugerir um comprometimento com o pressuposto discriminatório, segundo o qual, dado que estamos falando de conhecimento perceptivo, o que deve contar como evidência deve necessariamente funcionar como parte da ferramentaria para discriminar casos epistêmicos positivos de casos epistêmicos negativos.

Em resumo, o problema da distinguibilidade consiste em questionar como o DE poderia conciliar sua posição com o fato de que há casos que são indistinguíveis do ponto de vista introspectivo. A ideia é que 
parece se seguir do argumento que diz que se podemos deduzir competentemente e saber que estamos no caso epistêmico positivo, deveríamos ser capazes de distinguir introspectivamente entre este cenário e sua contraparte negativa. O que foi defendido até aqui nesta seção é que uma maneira de conceder a antecedente sem necessariamente conceder a consequente é estabelecendo uma distinção mais básica entre SEF e SED. Com base nisso, poderíamos defender que se Bia está de posse de suporte racional factivo reflexivamente acessível de que o animal enjaulado é uma zebra, a dedução competente que ela faz a partir destas razões, ou de razões de fundo acessórias, é o item responsável por fazer com que ela saiba que está no caso epistêmico positivo, e não uma capacidade perceptiva discriminatória extremamente exigente. Essa distinção mais básica, então, tem como função desfazer o paradigma tradicional sobre que tipo de evidência tem o poder de autorizar a nossa posse de conhecimento perceptivo e expandir esta noção de maneira que a avaliação do nosso conhecimento, quando da presença de possibilidades de erro, inclua o reconhecimento de que ela pode envolver bases epistêmicas que favorecem nossas crenças perceptivas frente a estas mesmas possibilidades. A distinção independente, desse modo, bloqueia o problema da distinguibilidade. E o DE de Pritchard, que incorpora tal distinção, estaria livre do ataque motivado pelo problema.

Uma pergunta importante neste momento é: o que isso tudo tem a ver com o problema cético radical? Esta é uma pergunta legítima, particularmente porque o problema cético local derivado do caso de Bia é consideravelmente diferente do ceticismo radical derivado do caso das Anas. Em especial, uma desanalogia importante está na ideia de que o paradoxo ilustrado pelo caso das Anas lança uma dúvida massiva contra o nosso conjunto de evidências, o que torna essa solução ineficaz contra ele. Em especial, a distinção entre SEF e SED não pode ser transportada automaticamente como método de resposta direta ao PCR-E. Afinal, o sujeito vítima da enganação massiva parece não estar autorizado a acessar suas evidências adicionais. No caso de Bia, o conhecimento de fundo que ela possui não está sob dúvida, portanto não há nada de errado em acessálo nesse caso. Portanto, os paradoxos parecem exigir soluções diferentes.

Para Pritchard, a dificuldade em separar apropriadamente os dois tipos de ceticismo contribui para que tratamentos do ceticismo local ignorem a distinção proposta por ele. Perceber que os casos são diferentes 
é fundamental para entender o papel da distinção quando estamos falando de casos de conhecimento perceptivo. Também é fundamental entender que a distinção entre os tipos de suporte evidencial, por si só, não pode dar conta de solucionar o problema gerado pelo paradoxo radical. O nó cético radical será largamente beneficiado pela distinção, mas para que ela cumpra sua função nesse caso precisa estar inserida em uma estratégia anticética mais ampla, que é a estratégia disjuntivista epistemológica proposta por Pritchard (PRITCHARD, 2012, p. 85).

No problema cético radical, o que o cético nos diz é que, dada a configuração do caso, as duas Anas estão de posse do mesmo tipo de evidência subjetivamente disponível, que não é capaz de oferecer ferramentas para que se distingua entre um cenário e o outro. Assim, de acordo com a premissa I do PCR-E, Ana não está de posse de um suporte epistêmico racional que favoreça sua crença frente à alternativa cética em questão. Segue-se naturalmente, então, que na ausência de evidência ou suporte racional que favoreça a crença na proposição-alvo frente à alternativa que ela sabe ser incompatível a esta crença, Ana ${ }_{\mathrm{o}}$ não pode ter conhecimento da crença-alvo. No entanto, o DE de Pritchard rejeitará a ideia de que Ana $_{\mathrm{o}}$ e Ana $_{\mathrm{n}}$ estão de posse do mesmo tipo de evidência de suporte epistêmico para suas respectivas crenças-alvo. Como vimos, Pritchard defende que o paradigma da discriminação perceptiva contido na recusa em atribuir conhecimento para Ana, ou sequer uma posição evidencial adequada, não está de modo algum em consonância com a maneira que pensamos sobre nossa prática epistêmica. Para ele, em casos paradigmáticos de conhecimento perceptivo nós precisamos sim estar uma posição epistêmica adequada em relação às nossas crenças, mas essa posição não precisa implicar que estejamos de posse de uma habilidade discriminatória especial para poder saber se somos como Ana ou como sua contraparte manipulada.

No caso de Bia, a lição extraída é que não devemos impor uma restrição indevida à sua posição evidencial com base na ideia de que tudo o que se configura como evidência advém daquilo que ela discrimina visualmente. A ideia nesse caso é que, em uma situação em que não há quaisquer razões para crer no contrário, Bia está de posse de razões factivas que favorecem sua crença de que o animal enjaulado é uma zebra e, por consequência, que são transmitidas para a negação das alternativas 
a essa proposição ("o animal é um urso", "o animal é um macaco", etc.). Bia vê que o animal é uma zebra e ver que algo é o caso, na ausência de derrotadores, é suficiente para nos colocar em posição adequada para conhecer tal proposição. No entanto, a coisa muda de figura quando a situação fica mais complexa, quando alguém levanta a hipótese de que o animal enjaulado não é uma zebra, mas uma mula minuciosamente disfarçada. A posição de Pritchard a esse respeito está dividida em duas. Por um lado, ele defende que meramente levantar uma hipótese cética desse tipo não deve, de modo algum, afetar o tipo de suporte epistêmico possuído por Bia na versão mais simples do caso. Se alguém diz que o animal talvez não seja uma zebra e sim uma mula disfarçada, mas sequer oferece razões em defesa de tal hipótese, Bia pode simplesmente reiterar sua posição e asserir que ela vê que o animal é uma zebra. Afinal, por que deveríamos nos abalar por qualquer possibilidade de erro lançada em nossa direção? Se não há uma motivação racional para tal possibilidade, não parece haver a necessidade de qualquer esforço de nossa parte em tentar reavaliar a nossa posição epistêmica. "Eu estou vendo que é uma zebra” parece uma resposta razoável frente à possibilidade de erros não motivadas racionalmente.

Por outro lado, entretanto, é fácil pensarmos nessa possibilidade de erro sendo racionalmente motivada. Alguém pode dizer a Bia que pensa que o animal pode ser uma mula disfarçada com base em uma informação que está circulando pela cidade que diz que a zebra daquele zoológico morreu, ou com base na informação de que há uma quadrilha especializada em roubos de zebras e substituição por mulas em zoológicos de cidades pequenas, e aquele zoológico foi vítima desse crime, etc. Nesse caso, dizer simplesmente "eu estou vendo que é uma zebra" não tem a força necessária para derrotar os derrotadores apresentados pela interlocutora. É necessário que Bia tenha sua posição epistêmica reforçada para que a possibilidade de erro racionalmente motivada não mine seu conhecimento de que o animal enjaulado é uma zebra. Ela pode dizer, por exemplo, que uma pessoa bem informada como ela teria ouvido tais informações circulando, e isso não aconteceu; ou que aquilo relatado como derrotador de sua crença sobre a zebra não possui qualquer plausibilidade, posto que, podemos supor, seria praticamente impossível roubar um animal desse porte, diante de todas as câmeras do zoológico e de todos os 
moradores da pequena cidade ${ }^{20}$. Em suma, independentemente do grau de motivação racional usado para questionar nossas crenças perceptivas básicas, ou ainda na ausência de um questionamento desse tipo, o DE autoriza que ofereçamos razões de suporte para nossas crenças-alvo que não pressupõem um comprometimento com o paradigma discriminatório. Ou seja, o DE nos autoriza oferecer razões do tipo SEF, quando estamos de posse delas, em defesa de nossas crenças perceptivas cotidianas, sejam tais razões factivas ou sejam elas razões empíricas de fundo.

Dito isso, poderia Ana $_{\mathrm{o}}$ afirmar, por exemplo, que a hipótese de que ela é como Ana $_{\mathrm{n}}$ é uma hipótese implausível, posto que, suponhamos, não há tecnologia avançada o suficiente para fazer tal procedimento de aprisionamento? Ou ainda, pelo que ela conhece de ciência cognitiva, seria impossível replicar de modo exato o cenário não-manipulado em um ambiente de enganação? Ainda que pareça plausível à primeira vista oferecer razões de fundo como derrotadores de uma hipótese que diz que talvez sejamos vítimas de uma enganação massiva, é simplesmente ineficaz fazê-lo. A razão para isto é que faz parte da própria natureza do problema em questão que a nossa posição epistêmica geral está sendo colocada em xeque e não apenas nossas razões para uma crença-alvo particular. Desse modo, com todo o nosso conhecimento posto em dúvida, é simplesmente incoerente citar razões de fundo como suporte epistêmico de favorecimento para a nossa crença em proposições cotidianas, como a crença de Ana de que ela tem duas mãos, e na negação das alternativas conhecidamente incompatíveis. Se uma hipótese cética radical coloca em questão quaisquer outras bases epistêmicas que poderíamos ter para sustentar crenças perceptivas cotidianas, de modo que o acesso a um tipo de suporte epistêmico de favorecimento em bases independentes não está disponível, como o DE pode responder de modo adequado ao problema cético radical?

Como vimos no caso de Bia, se há considerações epistêmicas em favor da possibilidade de erro em questão, Bia passa a precisar de um suporte racional independente, um tipo de suporte que não estaria disponível no caso de Ana. No entanto, segundo Pritchard, essas bases

\footnotetext{
${ }^{20}$ Prefiro deixar de lado, nessa discussão, qualquer complicador que apele para questões referentes a evidências testemunhais versus evidências de conhecimento de fundo. Reconheço, entretanto, que, ainda que não seja crucial para esse trabalho, tal discussão poderia ser feita e uma história mais complexa do SEF poderia ser oferecida.
} 
independentes de suporte não são necessárias quando não há possibilidades de erro incompatíveis epistemicamente motivadas em cena. Nesse caso, Bia está autorizada ${ }^{21}$ a excluir a possibilidade de erro com base no seu suporte racional factivo de que ela vê que há uma zebra na jaula. Para Pritchard, toda e qualquer alegação cética radical como a alegação discutida aqui será, em sua própria natureza, uma hipótese cética não motivada racionalmente. Afinal, ele nos lembra, a alegação cética radical não é que estamos de posse de razões empíricas em favor da hipótese cética. O problema não oferece quaisquer bases epistêmicas em favor da hipótese cética. O que o problema faz é mostrar que não somos capazes de conhecer sua negação. O que nos faz incapazes de ter conhecimento cotidiano, do ponto de vista cético radical, é justamente essa inabilidade em conhecer a (ou ter uma posição epistêmica adequada a respeito da) negação da hipótese cética em questão (PRITCHARD, 2012, p. 126-127).

A ideia central aqui é que a possibilidade de erro presente na hipótese cética radical é uma possibilidade de erro meramente levantada e nunca epistemicamente motivada. Ou seja, a possibilidade de erro contida no problema cético radical, a possibilidade de sermos cérebros em cubas sem qualquer experiência empírica real, é o equivalente radical da possibilidade não motivada no caso de Bia na qual nenhuma base é oferecida em favor da possibilidade de o animal ser uma mula disfarçada e não uma zebra. Sugerir o contrário, ou seja, conceber o problema cético radical como um que exige que a hipótese cética venha acompanhada de razões em favor dela, é conceber o cético radical como dotado de comprometimentos empíricos próprios, com convicções sobre o mundo que não fazem parte do trabalho adequado do ceticismo radical (PRITCHARD, 2012, p. 127). Afinal, o ceticismo radical construído da maneira apropriada é uma série de alegações intuitivas prima facie que constituem um paradoxo com base na inconsistência lógica entre elas e não necessariamente uma posição teórica que alguém defende considerando que "defender" aqui envolve oferecer razões apropriadas para tal. Conceber o ceticismo radical como posição e não como paradoxo é aceitar que se endosse uma tese específica em um cenário em que qualquer ato de endosso teórico se torna suspeito, seja ele na forma da

\footnotetext{
${ }^{21}$ Pritchard usa o termo "entitled" para se referir ao tipo de autorização que agentes como Bia possuem em casos do tipo.
} 
negação epistemicamente motivada da premissa anticética ou da premissa cética do paradoxo. O propósito de construir o problema em termos de paradoxos é mostrar que há uma "tensão profunda e fundamental entre nossos conceitos epistemológicos” (PRITCHARD, 2012, p. 127), sem necessariamente oferecer razões em favor de uma ou outra posição. Para Pritchard, qualquer forma de ceticismo que incorpore um apelo a bases empíricas de suporte epistêmico para a hipótese cética radical terá que arcar com as consequências teóricas disso, como ter que esclarecer quais comprometimentos empíricos específicos o cético deve ter ou esclarecer em que sentido sua posição se salvaria de problemas de autorreferência e autorrefutação.

A posição disjuntivista consiste então em reconhecer que, dado que casos céticos radicais, em sua natureza, não são motivados racionalmente, não há qualquer necessidade de se apelar para um suporte epistêmico empírico em favor da rejeição da possibilidade de erro. Desse modo, o DE faz a defesa de que a posse de suporte racional reflexivamente acessível na forma das razões factivas é suficiente para oferecer uma resistência e uma resposta ao problema cético radical. O que se espera de uma posição anticética direcionada ao PCR-E é que nela seja oferecida uma maneira apropriada de rejeitar a ideia de que nosso suporte racional em casos epistêmicos positivos não é melhor que o suporte que temos em casos negativos correspondentes. Se o que foi exposto até aqui está correto, então o DE se coloca como uma posição capaz de rejeitar essa ideia e de garantir que tenhamos uma posição epistêmica adequada com relação às nossas crenças cotidianas e à negação das alternativas de erro relevantes.

Pritchard apresenta, então, uma estratégia anticética canalizada pelo DE. Sua posição é a de que a premissa cética do PCR-E, a premissa I, se apoia em pressupostos teóricos duvidosos, as teses NG e TIR - que, se o DE estiver correto, são mostradas patentemente falsas - e não sobre a maneira que normalmente concebemos nossa prática epistêmica. Desse modo, não há qualquer concessão de plausibilidade às teses, à premissa I do PCR-E e ao problema cético motivado por essa via. Para o DE de Pritchard, o PCR-E está sustentado por pressupostos falsos, por isso seu problema é ilusório. A combinação da distinção SEF/SED e da proposta disjuntivista acerca da natureza do nosso suporte epistêmico em casos paradigmáticos de conhecimento perceptivo (casos em que não há 
qualquer alternativa cética motivada racionalmente) nos possibilita então oferecer uma resposta ao PCR-E que, se estiver correta, desfaz um importante nó cético presente no debate epistemológico contemporâneo.

\section{Considerações finais}

Respostas contemporâneas ao problema cético radical assumem formas diversas no cenário epistemológico atual. O DE é apenas uma das mais recentes a ganharem destaque nesse cenário. Em grande parte, esse destaque se deve ao trabalho dedicado e detalhista de Pritchard, na sua tentativa de organizar o debate e de explorar os caminhos que uma estratégia anticética pode seguir em busca de sua solução. Neste trabalho, eu quis explorar, rapidamente, a natureza do problema cético radical e como o disjuntivismo epistemológico é, segundo Pritchard, uma maneira de responder apropriadamente a pelo menos uma formulação do paradoxo cético radical.

Para isso, apresentei os pressupostos disjuntivistas mais gerais, desde o que significa dizer que uma posição é disjuntivista até o que entendemos quando dizemos que uma experiência perceptiva verídica é epistemicamente distinta de uma experiência perceptiva enganadora. Assim, tratei de mostrar sobre quais bases mcdowelleanas Pritchard se apoia para construir sua proposta e em que sentido esta se diferencia do disjuntivismo sobre a evidência perceptiva que McDowell articulou. Ao final, então, discuti de que maneira sua versão do DE pretende sustentar uma distinção independente mais básica entre os tipos de base evidencial que precisamos estar de posse para que possamos conhecer perceptivamente, e como a aliança entre essa distinção e os pressupostos disjuntivistas pode contribuir não só para uma resposta promissora a uma forma popular de ceticismo local, mas também aparenta apontar para uma possível solução de uma forma epistemicamente devastadora de ceticismo radical $^{22}$.

\section{Referências Bibliográficas}

BONJOUR, Laurence. The Structure of Empirical Knowledge. Cambridge: Harvard University Press, 1985;

\footnotetext{
${ }^{22}$ Agradeço aos/às editores/as da Veritas pelo trabalho dedicado e aos/às referees por todas as críticas e sugestões, que foram acatadas em sua maioria e que, com certeza, contribuíram para maior clareza e precisão do texto.
} 
B. R. G. Santos - Disjuntivismo epistemológico e ceticismo radical | 655

BRUECKNER, Anthony. The structure of the skeptical argument. Philosophy and Phenomenological Research, v. 54, n. 4, p. 827-835, 1994;

BURGE, Tyler. Disjunctivism and perceptual psychology. Philosophical Topics, v. 33, n. 1, p. 1-78, 2005;

BURGE, Tyler. Disjunctivism again. Philosophical Explorations, v. 14, n. 1, p. 43-80, 2011;

COHEN, Stewart. Two kinds of skeptical argument. Philosophy and Phenomenological Research, v. 58, n. 1, p. 143-159, 1998;

CONEE, Earl e FELDMAN, Richard. Internalism Defended. In: KORNBLITH, Hillary. Epistemology: Internalism and Externalism. Oxford: Blackwell, 2000;

DAVIES, Martin. Epistemic Entitlement, Warrant Transmission and Easy Knowledge. In: Aristotelian Society Supplementary Volume. The Oxford University Press, 2004;

DRETSKE, Fred. Epistemic Operators. The Journal of Philosophy, v. 17, n. 24, 1970;

HUAPING, W. A. N. G. Disjunctivism and skepticism. Frontiers of Philosophy in China, v. 6, n. 3,2011 ;

LOGUE, Heather. Disjunctivism. In: The Oxford Handbook of Philosophy of Perception. Oxford University Press, 2015;

MACARTHUR, David. McDowell, scepticism, and the veil of perception. Australasian Journal of Philosophy, v. 81, n. 2, 2003;

MCDOWELL, John. Criteria, defeasibility, and knowledge. Proceedings of the British Academy, n. 68, p. 455-79, 1982;

MCDOWELL, John. Knowledge and the Internal. Philosophy and Phenomenological Research, v. 55, n. 4, 1995;

MCDOWELL, John. Mind and world. Harvard University Press, 1996;

MCDOWELL, John. Knowledge and the internal revisited. Philosophy and Phenomenological Research, v. 64, n. 1, 2002;

MCDOWELL, John. The disjunctive conception of experience as material for a transcendental argument. In: Disjunctivism: Perception, Action, Knowledge. Oxford: Oxford University Press, p. 376-89, 2008;

MCDOWELL, John. Tyler Burge on disjunctivism. Philosophical Explorations, v. 13, n. 3, p. 243-255, 2010;

MCDOWELL, John. Tyler Burge on disjunctivism (II). Philosophical Explorations, v. 16, n. 3, p. 259-279, 2013; 
656 | Veritas | Porto Alegre, v. 62, n. 3, set.-dez. 2017, p. 624-656

PRITCHARD, Duncan. McDowell on reasons, externalism and scepticism. European Journal of Philosophy, v. 11, n. 3, 2003;

PRITCHARD, Duncan. The structure of sceptical arguments. The Philosophical Quarterly, v. 55, n. 218, p. 37-52, 2005;

PRITCHARD, Duncan. McDowellian neo-mooreanism. In: Disjunctivism: Perception, action, knowledge, p. 283-310, 2008;

PRITCHARD, Duncan. Evidentialism, internalism, disjunctivism. Evidentialism and its Discontents, p. 235-253, 2011;

PRITCHARD, Duncan. Epistemological disjunctivism. OUP Oxford, 2012;

PRITCHARD, Duncan. Epistemic Angst. Princeton University Press, 2015;

PRYOR, James. Highlights of Recent Epistemology. British Journal for the Philosophy of Science, n. 52, pp. 95-124, 2001;

SNOWDON, Paul. The formulation of disjunctivism: a response to Fish. Proceedings of the Aristotelian Society. The Oxford University Press, p. 129-141, 2005;

THAU, Mike. What is disjunctivism?. Philosophical Studies, v. 120, n. 1, p. 193-253, 2004;

TYE, Michael. Intentionalism and the argument from no common content. Philosophical perspectives, v. 21, n. 1, p. 589-613, 2007;

VOGEL, Jonathan. Skeptical arguments. Philosophical issues, v. 14, n. 1, p. 426-455, 2004;

WRIGHT, Crispin. Some reflections on the acquisition of warrant by inference. New essays on semantic externalism and self-knowledge, p. 57-77, 2003;

WRIGHT, Crispin. Warrant for Nothing (and Foundations for Free)?. In: Aristotelian Society Supplementary Volume. The Oxford University Press, 2004;

YALÇIN, Ümit D. Skeptical arguments from underdetermination. Philosophical Studies, v. 68 , n. 1 , p. $1-34,1992$

\section{Endereço postal:}

Programa de Pós-Graduação em Filosofia -PPG/FIL, Universidade de Brasília - UnB

Campus Darcy Ribeiro, ICC Norte, lado B, coluna 615, Mezanino Campus Universitário Darcy Ribeiro, Brasília - DF, Brasil

Data de recebimento: 25-05-2017

Data de aceite: 04-12-2017 